\title{
Achega á presenza (ou ausencia) do galego e a súa literatura en Dinamarca: estudo, tradución e coñecemento
}

\author{
An Approach to the Presence (or Absence) of Galician and Its Literature \\ in Denmark: Academia, Translation and Awareness
}

\author{
Vanesa Rodríguez TEMBRÁs \\ Universidad Complutense de Madrid \\ Departamento de Filología Románica, Filología Eslava y Lingüística General \\ vrtembras@ucm.es
}

[recibido 31/10/2014, aceptado 01/02/2015]

\section{RESUMO}

Este estudo céntrase na procura da pegada do galego, a súa literatura e cultura galega no país nórdico. Ó decatarnos do descoñecemento e a ausencia da nosa lingua en ámbitos académicos, editoriais e sociais dinamarqueses, rastrexamos as debilidades e fortalezas da posibilidade da implementación do galego e a súa literatura en Dinamarca.

PALABRAS CHAVE: Galego, literatura galega, Dinamarca, tradución, países nórdicos.

\section{RESUMEN}

Este estudio se centra en la búsqueda de la huella del gallego, su literatura y cultura en el país nórdico. Al percatarnos del desconocimiento y la ausencia de nuestra lengua en ámbitos académicos, editoriales y sociales daneses, rastreamos las debilidades y fortalezas de la posibilidad de la implementación del gallego y su literatura en Dinamarca.

PALABRAS CLAVE: Gallego, literatura gallega, Dinamarca, traducción, países nórdicos.

\section{ABSTRACT}

This study focuses on exploring the influence of Galicia, its literature and its culture, in Denmark. On realizing a lack of awareness and an absence of our language in the Danish academic circles, their publishers and other social circles, we ascertain the weaknesses and strengths of a possible implementation of Galician and its literature in Denmark.

KEY WORDS: Galician, Galician Literature, Denmark, translation, nordic countries.

Rodríguez Tembrás, V. (2015): “Achega á presenza (ou ausencia) do galego e a súa literatura en Dinamarca: estudo, tradución e coñecemento”, Madrygal (Madr.), 18, Núm. Especial: 579-590.

SUMARIO: 1. Introdución. 2. A presenza ou o estado da cuestión. 2.1. Investigacións locais: a visibilización interior. 2.2. O mundo editorial e as traducións. 2.3. A percepción no lado dinamarqués. 2.4. O galego e a institución universitaria en Dinamarca. 2.5. O referente nórdico: Finlandia. 3. A ausencia ou a oportunidade. 3.1. O proxecto. 3.2. As axudas e subvencións. 4. Conclusións. 5. Referencias bibliográficas. 


\section{INTRODUCIÓN}

Dende finais do século XIX até os nosos días, contando con puntos chave entre os anos 1885 e $1930^{1}$ ou os anos da ditadura franquista, moitos homes, e tamén mulleres, víronse obrigados a buscar sustento máis alá das nosas fronteiras. A diáspora galega tan mencionada e culturalmente prolífera é un factor fundamental para entender o desenvolvemento da nosa cultura, tal como salienta Manuel González, daquela Secretario da Real Academia Galega: "Hai ademais unha característica que marcou a historia de Galicia dunha maneira moi especial: a emigración. A emigración cara a América ata a década dos 60 do século pasado, e a emigración cara a Europa, a partir desta época" (González 2006: 389).

Na actualidade, nos primeiros anos do século XXI, atopamos o mesmo fenómeno auspiciado pola crise económica mundial. Do mesmo xeito que outros españois, os galegos teñen de novo ante si a necesidade de progresar fóra do noso país. Segundo datos da Xunta de Galicia, o número de emigrantes galegos aumentou arredor dun $30 \%$ nos últimos 10 anos; isto é, no ano 2002 a cifra roldaba os 275000 emigrantes fronte ós pouco máis de 400000 inscritos o ano pasado (2013) 2 .

Para rematar cos datos estatísticos, unha pequena referencia a Dinamarca, o país que nos ocupa nesta aproximación á presenza ou, como veremos máis adiante, a ausencia do galego e da súa literatura no país nórdico. O número de galegos vivindo en Dinamarca redúcese a 128 , no total de 100000 habitantes nados en Galicia noutras nacións europeas. A tímida cifra é similar ós dinamarqueses que viven na nosa terra, que son 86 repartidos polas catro provincias galegas.
O sentimento de estar lonxe da túa terra, da contorna próxima e cómoda, é común e internacional. Por regra xeral, esta saudade á que os galegos lle inventamos unha palabra, a morriña, leva consigo a necesidade de pertenza a ese grupo de "iguais". Os centros galegos sociais, e outros tantos de estudos galegos, repártense pola xeografía mundial. Contamos cun total de 255 centros emigrantes, dos cales 185 están situados fóra de España (Suárez e Gaiferos 2011: 19).

A difusión exterior da lingua galega debe atender a dúas vertentes nidiamente diferenciadas: dar a coñecer internacionalmente a lingua galega e espertar o interese polo seu estudo, como elemento vehicular dunha cultura; atender as necesidades lingüísticas dos nosos emigrantes e dos seus descendentes, de xeito que non se consideren desenraizados e que manteñan vivos os vencellos coa do seu pobo, independentemente do lugar do planeta en que se atopen. (González 2006: 389)

O número de Centros de Estudos Galegos, dos cales falaremos máis adiante, é $43^{3}$ : dez dos centros encóntranse dentro da Península, doce fóra de Europa e os 21 restantes en Europa.

Despois da aprobación do Estatuto de Autonomía de Galicia, o Goberno galego subscribiu, especialmente nas dúas últimas décadas, unha seria de convenios con universidades de distintos países de cara a fomentar o ensino da lingua galega e da súa cultura. Mediante estes convenios creáronse nestas universidades uns Centros Galegos. (González 2006: 390)

Segundo Manuel González, ex-secretario da Real Academia Galega e catedrático da USC, as tres características fundamentais destes centros son os seguintes: "a incorporación do ensino da lingua galega aos programas de

\footnotetext{
1 “A emigración española en xeral foi moi importante. Os expertos sinalan que máis de cinco millóns de emigrantes abandoaron España entre a década de 1850 e a de 1970, como dato bruto máis ca neto, dos cales moitos regresaron (...) Os galegos foron os máis números dos emigrantes da España peninsular, supoñendo o 36\% do total" (Núñez 2002: 219, apud Suárez e Gaiferos 2011: 15).

${ }^{2}$ Datos consultados no informe da Xunta "A emigración en cifras 2013": http://emigracion.xunta.es/ conecendo-galicia/aprende/a-emigracion-en-cifras (última consulta: 05/09/2014).

${ }^{3}$ Dos 43 , trece non teñen un lector proporcionado pola Xunta de Galicia.
} 
estudos da universidade; a apertura dunha sección dedicada ao galego dentro da biblioteca do centro e o desenvolvemento dunha serie de actividades culturais de fomento da lingua e cultura galegas ao longo de cada curso académico" (González 2006: 390). Ademais, apunta cara a un elemento fundamental para entender o traballo dos investigadores, que divulgan a nosa lingua, literatura e cultura alá onde van, os cales tamén promoven doutoramentos e memorias de licenciatura ou mestrado: a divulgación, a propagación do coñecemento é vital para a pervivencia dunha lingua e dunha cultura, os símbolos dun pobo.

Non hai dúbida de que o principal factor de identidade que posúe Galicia é a súa lingua. (...) na conformación da identidade dos pobos é tamén moi importante o recoñecemento exterior: existimos porque somos, pero tamén porque os demais recoñecen que existimos. De aí a importancia que ten para os galegos dar a coñecer a súa lingua e a súa cultura. (González 2006: 389)

Quereriamos subliñar esta reflexión filosófica e contundente do catedrático: "Existimos porque somos, pero tamén porque os demais recoñecen que existimos" (González 2006: 389). E este é o labor dos profesores, investigadores, institucións e cada un dos galegos que, vaian onde vaian, han de lembrar que os define como comunidade.

A proxección exterior da lingua galega é un labor complexo (...) o logro de certo status xurídico e presenza real dentro da Unión Europea, a promoción da cultura nas súas diferentes manifestacións vehiculadas nesta lingua, o fomento do interese internacional pola investigación sobre as múltiples caras que presenta unha realidade poliédrica como é unha lingua, o fomento da tradución dos nosos escritores a outras linguas, o ensino do galego fóra do territorio que lle é propio, etc. (González 2006: 389)

A elaboración desta investigación partiu dunha necesidade persoal de investigar con maior profundidade un descoñecemento evidente. O galego e a literatura galega son uns auténticos descoñecidos no país; porén, Carlos Núñez é amplamente coñecido. Galicia ten un oco no mapa cando se presenta da man do gran músico e a súa gaita; non así se mencionamos nomes de pesos pesados como Rosalía de Castro, Castelao ou, máis achegado ó noso tempo, Manuel Rivas. Con Carlos Núñez, Galicia ten un nome, un respecto, unha banda sonora. Galicia é ese recuncho celta vinculado á música dos irlandeses "The Chieftains", grupo que acompañaba o músico galego no Festival de Tønder ${ }^{4}$ e que provocou esta conversa e esta dúbida.

Desta curiosidade por saber que sabía o noso país de acollida sobre as nosas raíces galegas, levaríanos directamente a propoñer un esquema de implantación. Unha achega, una presentación progresiva do que a nosa cultura pode ofrecer ó país nórdico.

A gran cuestión a responder ou procurar unha achega a esta resposta é: que fai falta para que ocorra este mesmo recoñecemento e admiración respecto á nosa literatura? Os dous vértices principais serían a propia consideración interna da nosa cultura e, unha vez conseguida esa posición privilexiada, de respecto e protección; ofrecer a nosa cultura a novos mercados ou países. Unha divulgación interior e exterior que leve consigo unha normalización e, polo tanto, a unha valorización do noso, unha actitude nos últimos tempos en franco retroceso.

\section{A PRESENZA OU O ESTADO DA CUESTIÓN}

O primeiro obstáculo a derrubar foi a investigación partindo dun descoñecemento, polo tanto sen testemuñas bibliográficas específicas referentes a Dinamarca ou experiencias previas a ter en conta. Unha lagoa de coñecemento, ese oco libre para o estudo e a expansión que supón o país nórdico para a divulgación da literatura galega. Este título presentado

${ }^{4}$ Tønder é una pequena vila situada no sur de Dinamarca, xusto na fronteira con Alemaña. O seu Festival Folk é moi coñecido no país, sendo un dos de maior referencia dende fai máis de 30 anos. 
como "presenza" ben podería amosarse como unha compilación de liñas de estudo que foron rastrexadas para esta achega.

A primeira decisión a tomar sería a busca de persoas de referencia que puidesen fornecer o seu punto de vista para construír unha reflexión poliédrica desde os cimentos da cuestión a debater. Outra importante consideración sería entender o país de Dinamarca como unha peza do gran conxunto dos países escandinavos, sen esquecer as súas singularidades culturais e comerciais.

\subsection{INVESTIGADORES LOCAIS: A VI- SIBILIZACIÓN INTERIOR}

Salvador Castro e Henrique Harguindey, profesores de galego de secundaria e autores de Urbi et Orbi: Dende o galego para o mundo $o^{5}$, representan o primeiro chanzo desta escaleira ata a proxección da nosa lingua e literatura ou, en definitiva, da nosa cultura. Nesta obra, concibida como presentación para os seus alumnos, para que viran a presenza da literatura galega no mundo, Salvador Castro subliña a súa motivación principal dicindo que estaban "preocupados pola imaxe tan empobrecida que os nosos alumnos tiñan da lingua galega"6. O libro consta de reproducións de traducións de autores galegos, que escribiron os orixinais en galego, a outras linguas no mundo. Unha proposta interesante que esperta outros debates sobre as traducións, que recuperaremos máis adiante.

Acaso non hai nada que axude máis a medrar que a capacidade de asombro, a sensibilidade que nace do rexeitamento da indiferenza como actitude vital. Ao noso carón están presentes realidades fecundas que non percibimos a forza de non contemplalas con ollos virxes. (Castro, Harguindey, Martínez e Rocamonde 2011: 7)

Esta reflexión dos autores, "a contemplación con ollos virxes", é unha das ideas principais que rodean todo este estudo. Un libro que serviu como punto de ignición para constatar que non existen traducións do galego ao dinamarqués, estritamente falando, sen considerar textos escritos por escritores galegos en lingua castelá. Polo tanto, antóllase un pouco quimérica a busca dunha percepción positiva por parte da comunidade danesa ante a nosa literatura. Eses "ollos virxes", apuntados en Urbi et Orbi, tamén son, se lle damos a volta á cuestión, unha oportunidade para a exploración de novos mercados. Os seus ollos virxes poden servir para unha aceptación da novidade, sen prexuízos, un criterio que desenvolveremos con máis detemento no apartado de proposta de implementación.

O máis triste é que aquí, no país, persoas que deberían coñecer, destacar e fomentar a nosa cultura, cualifícana de "ensimesmada e pechada", como se fose menos universal falar das memorias dun neno labrero ca das peripecias dunha familia de Oklahoma explotada pola usura capitalista durante a Gran Depresión. (...) Non deixa de ser curioso que se empregue $o$ adxectivo pechada para se referir a unha literatura chea de Simbad, de Merlín, de Percival e tantos outros personaxes de acolá". (Castro, Harguindey, Martínez e Rocamonde 2011: 7)

\subsection{O MUNDO EDITORIAL E AS TRA- DUCIÓNS}

"A primeira idea que desexo enunciar é que somos absolutamente invisibles" (Méndez Ferrín 2013: 36). Estas palabras tan contundentes e catastrofistas están asinadas por Xosé Luís Méndez Ferrín, un dos grandes da nosa literatura e, no momento de escribir estas liñas, Presidente da Real Academia Galega, serven para describir en poucas palabras a importancia da tradución e das boas alianzas das editoriais entre países, para levar a cabo un intercambio vantaxoso e fluído de obras. Unha lingua minoritaria ten que facer fronte a un dobre obstáculo e precisa dun apoio institucional máis sólido.

\footnotetext{
${ }^{5}$ Comparten autoría con Xosé Martínez e Ramón Rocamonde.

${ }^{6}$ Declaracións extraídas dunha entrevista persoal de elaboración propia.
} 
Engádese no caso das minorizadas, a circunstancia de concorreren desde a súa condición de cultura sen estado, o que implica que non contan cos mesmos medios de que goza unha cultura estatal (forte ou feble) en termos institucionais e comerciais para a produción, difusión e presentación dos seus bens culturais no exterior. (Galantes Santos 2013: 267)

Méndez Ferrín, no mesmo discurso, ofrecía unha dobre solución ó problema. "Hai, xa que logo, dúas posibilidades: incitarmos, producirmos nós as nosas propias traducións, ou agardamos ao recoñecemento no estranxeiro dos nosos autores e autoras. Sen dúbida, esta segunda vía é máis desexable" (2013: 37).

A profesora Galanes Santos, pola súa banda, presenta outra barreira a derrubar e que complica a cuestión. "O feito de que un libro galego sexa traducido no exterior non implica en por si que se estea a internacionalizar a literatura galega, pois para que esta teña lugar cómpre que a obra cause algún impacto na cultura de recepción" (Galanes Santos 2013: 281). Nesta liña, a autotradución, entendida como punto intermedio entre creación e tradución, é unha opción.

Os cada vez máis numerosos contactos entre linguas, grazas á maior mobilidade de poboación, en tódolos niveis, en todo o mundo, e o claro reforzamento do sistema xerárquico entre as linguas afectan ó universo literario e están directamente relacionados coa práctica da autotradución. (Recuenco Peñalver 2013: 207)

A autotradución, unha actividade moi común nas rexións bilingües, podería ser una ferramenta a ter en conta para achegar a literatura, aínda que o escenario a perseguir sería unha tradución directa e en base ó recoñecemento da cultura receptora.

Canto ás traducións que se fan ao galego de linguas estranxeiras contribúen, alén da difusión de autores estranxeiros (angueira que está presente en Galicia desde o século XIX), ao fortalecemento, á 'musculación' da lingua galega como lingua literaria. Non esquezamos que o proceso de constitución dunha lingua literaria é cousa dos escritores, dos lectores e mais dos intermediarios entre ambas as partes, é dicir, aqueles que recomendan (ou censuran os libros) e, por suposto, dos profesionais das traducións que exercitan a lingua galega, sométena a novos desafíos. (Méndez Ferrín 2013: 39)

Dos 1300 títulos galegos que temos traducidos a outras linguas, ningún foi traducido ó dinamarqués ${ }^{7}$. Outro dato cuantitativo é o que nos ofrece a profesora Galanes, "existe literatura galega traducida a 47 comunidades culturais en 37 linguas e máis de 1400 monografías traducidas" (Galanes Santos 2013: 285).

Silvia Montero, investigadora da Universidade de Vigo, destaca o papel das editoriais, como intermediarias para a divulgación de novos títulos e novas literaturas: "As editoriais participan de xeito decisivo no desenvolvemento cultural dunha sociedade, pois controlan as fases de selección, produción e incluso o proceso de recepción dunha estética" (Montero Küpper 2013: 44).

A autora do artigo "As políticas de tradución no caso galego" subliña a importancia da tradución como unha actividade que "cumpre unha especial función normalizadora, non só

\footnotetext{
${ }^{7}$ Os datos recollidos neste estudo, na espera dun compendio máis exhaustivo, fiable e rigoroso, parten do confronto do Index Translationum elaborado pola Unesco e o Catálogo de obras literarias en lingua galega traducidas a outros idiomas, da man do Consello da Cultura Galega (1977 a 2003) e dirixido por Carlos Casares. Neste dato só se toma como referencia o Index Translationum. Ámbolos dous non teñen datos anteriores ós anos 70, o cal non sería relevante no período de silenciamento do galego durante a ditadura de Franco. Como información suplementaria, gustaríanos indicar os datos de traducións do catalán ou éuscaro en Dinamarca, sempre tomando como referencia o Index Translationum: o catalán posúe dez obras de nove autores diferentes traducidos e, no caso do éuscaro, atopamos catro obras de Bernardo Atxaga. Outra investigación levaríanos a ter en conta aqueles escritores de orixe galega que escribiron a súa obra en castelán, os cales non foron considerados para os cómputos ofrecidos nesta achega.
} 
en relación co uso (normal) da lingua, senón tamén en relación cun recoñecemento interno e externo da identidade galega" (Montero Küpper 2013: 58). Un parágrafo que sintetiza a esencia dun pensamento primordial para entender a importancia da tradución no labor da visibilización e consolidación da literatura en galego en particular, e a cultura en xeral, no panorama internacional. A mesma reflexión que faría Iolanda Galanes, tamén profesora da Universidade de Vigo, quen destaca en relación ás funcións da tradución, os seguintes feitos:

En primeiro lugar, é un indicador das relacións interculturais entre dúas comunidades. En segundo lugar, que se produza a tradución implica un recoñecemento do valor literario dunha cultura noutra, o ben cultural adquire capital simbólico tanto no exterior como dentro do seu propio sistema. En terceiro lugar, a tradución implica a visibilidade exterior e constitúe, polo tanto, un factor de canonización da obra, autor/a, xénero ou cultura en cuestión. En cuarto lugar, o volume dos intercambios e a recepción que estes teñan contribuirán a posicionar a cultura de orixe no panorama internacional. E, en últimos lugar, a tradución evidenciará a relación de forzas entre sistemas e a súa análise as prácticas culturais que favorecen os intercambios. (Galantes Santos 2013: 267)

Pode parecer, nunha primeira lectura, que dende esta achega se presta máis atención á tradución que a outros factores sintomáticos desta posibilidade de exportación cultural; no entanto, consideramos que este exemplo de tradución é aplicable a outros aspectos relativos ó proceso de implementación da literatura galega en Dinamarca. Son factores que se poden extrapolar á súa xeneralidade e ofrecen unha visión ben clara da importancia e complexidade do tema a estudar. Porén, a tradución ó idioma obxectivo é un dos momentos primordiais para a exportación dunha literatura a outro país ou rexión con idioma propio.

Para rematar, citaremos a Carlos Casares, quen tamén ofreceu as súas valoracións sobre este feito:
Nas sociedades contemporáneas a vitalidade da súa cultura mídese pola súa visibilidade. Por como se relaciona coas outras. Na súa capacidade de contar e achegar ao concerto de todas o debate, a reflexión ou o entretemento. Un dos maiores indicadores de visibilidade é o interese pola tradución, polo transporte do pensamento e da creación intelectual para que sexa comprensible noutras culturas e por outra xente. Un dos mellores indicadores da saúde da nosa literatura o do interese que esperta no exterior é coñecer que autores, que obras e a que linguas foron traducidas. (Casares 2003: 2)

\subsection{A PERCEPCIÓN NO LADO DINA- MARQUÉS}

Co obxectivo de ofrecer unha achega rigorosa -aínda que, como achega, de maneira parcial- a este tema que nos ocupa, diremos que a falta dunha enquisa profesional a valoración xeral apreciada ó longo deste estudo é que existe un descoñecemento da existencia da nosa lingua e literatura. Non é de estrañar, cando non existen traducións, o galego non forma parte dos programas universitarios, nin tampouco hai un Centro de Estudos Galegos de referencia ou un centro emigrante. Como xa mencionamos na introdución, a presenza galega no país é moi reducida, aínda que non sería óbice para a introdución e difusión da súa cultura. Méndez Ferrín explica ó respecto as diferenzas mercantís das literaturas de linguas maioritarias e as minoritarias.

Ocorre que, polo xeral, as grandes editoriais de lingua inglesa non se interesan por ningunha literatura que non sexa das grandes, isto é, a inglesa, a francesa, a italiana ou a alemá e pouco máis, na medida en que o relevante xa non é o número de falantes, senón a importancia das literaturas no concerto internacional, na que poderiamos denominar 'a ONU das literaturas'. (Méndez Ferrín 2013: 36)

Morten Dürr, escritor e xornalista danés, sinala que no seu país "ademais dos best-sellers, o que se publica baséase no gusto persoal do editor, o que podes tamén ti facer se pos en marcha a túa propia editorial"". Do mesmo

\footnotetext{
${ }^{8}$ Declaracións extraídas dunha entrevista persoal de elaboración propia.
} 
xeito, expresaba o seu descoñecemento e interese por saber o que a literatura galega podería ofrecerlle. O mercado danés non resulta moito máis exótico que outro das mesmas características. Na mesma liña que Dürr, a investigadora Luna Alonso engade que se traduce "o que se considera de prestixio ou innovador, mais o fenómeno da tradución, mesmo cando se trata de obras publicadas en formato libro, aínda ten a súa orixe en motivacións persoais ou apetencias propias dos axentes mediadores" (2005: $33)$.

As características especiais dunha exportación a un mercado emerxente han de cumprir certas garantías e levarse a cabo un estudo previo, un termo que excede as posibilidades desta achega, xa que, como ben nos alerta a profesora Galanes Santos, "Para que unha tradución se produza ten que existir, cando menos, dúas culturas que por calquera motivo entren en relación, unha axente cultural que sirva de ponte entre ambas e as condicións mínimas para que esta relación cristalice" (2013: 266). Así e todo, como veremos deseguido, o referente finlandés é un punto a favor para a aceptación, ademais doutras presenzas, aínda feble en Noruega e Suecia, das traducións de novelas de Manuel Rivas e Domingo Villar (cf. supra 2.1).

\subsection{O GALEGO E A INSTITUCIÓN UNI- VERSITARIA EN DINAMARCA}

A presenza do galego nas institucións universitarias danesas é, en resumo, inexistente. Porén, o castelán e o portugués son linguas integradas nos programas e con cada vez mellor acollida. O galego tería, pois, un oco no medio destas dúas linguas para así encaixar nos graos impartidos. Deste xeito, ocorrería coma en universidades europeas que de feito ofrecen galego, polo que non resultaría innovador, agrupándose en departamentos normalmente chamados de "Linguas Modernas". O galego, a pesar do que se poida considerar a priori, agás o catalán, é a lingua minoritaria con maior presenza nas universidades estranxeiras. A gran presenza de galegos na diáspora é un factor determinante, ó que xa fixemos referencia, xa que crea vínculos culturais co país de acollida.
A nosa enquisa sobre a situación das linguas rexionais ou minoritarias en varias universidades europeas, nas cales poden ser estudadas, ensínanos que o galego e, despois do catalán, a segunda lingua más ensinada en estas universidades. (Suárez e Gaiferos 2011: 54)

$\mathrm{Na}$ actualidade, existen 44 Centros de Estudos Galegos en universidades fóra de Galicia, dos cales 29 están en Europa: Francia, Alemaña, Reino Unido, Hungría, Croacia, Irlanda, Italia, Portugal, España e Finandia. Este último é de grande importancia para o noso estudo, toda vez que sería o único existente en todo o conxunto de países nórdicos. Polo tanto, como se recollerá nunha segunda parte de propostas e conclusións, resultaría relevante un segundo Centro de Estudos Galegos en Dinamarca, un país con gran conexión con Alemaña e, por suposto, cos restantes países de cultura nórdica.

Os seus obxectivos son a promoción dos intereses de Galicia no mundo académico, tanto na ensinanza coma na investigación, do mesmo xeito que a contribución na creación dunha área de educación superior europea, en particular; e para a integración europea en xeral. (Suárez e Gaiferos 2011: 66)

A demanda do galego aumenta en liñas xerais nas universidades non españolas onde se imparte, agás no Reino Unido. Os profesores Suárez e Gaiferos da Universidade de Deusto elaboraron unha enquisa en tódalas universidades que contan cun lector fornecido pola Xunta de Galicia. Por exemplo, indícanos que "en xeral, podemos dicir que matriculación deu un salto en París, onde nos últimos anos aumentou de 15 alumnos en 2008 a 50 no 2010, e en Tubinga, donde pasou de 9 en 2005 a 59 en 2010" (2011: 55). Cales son as motivacións destes estudantes que poden servir de inspiración para os que poidan escoller galego no futuro?

Os resultados da enquisa móstranos que aqueles que escollen estudar galego fóra de España teñen diversos intereses. Para os descendentes de emigrantes de Galicia, e unha reprodución cultural, xunto con outras consideracións utilitarias, por exemplo; a posibilidade de voltar á terra dos seus familiares. Para outros, é un interese na diversidade lingüística 
en España, quen estudan a lingua maioritaria: o castelán. Aínda que para outros, como aqueles que se adican ós estudos románicos, o galego é tamén moi relevante; como foi o occitano, unha das linguas europeas máis prestixiosas na Idade Media (...) Outra razón sería o interese na lingua galega e a súa cultura co fin de participar un programa de intercambio Erasmus. (Suárez e Gaiferos 2011: 68)

A universidade tamén xoga un papel determinante no mundo editorial e as traducións. A demanda dos estudantes crea una necesidade comercial, tanto na lingua orixinal como as traducións, ó comezar, nun contexto ideal, a expandirse o coñecemento de certas obras ou autores e a asentarse a súa valorización. As editoriais que adoitan atender a estas demandas son as de menor tamaño.

\subsection{O REFERENTE NÓRDICO: FINLANDIA}

$\mathrm{Xa}$ mencionamos que a tradución dunha obra ha de responder a algún vínculo cultural entre os dous países ou rexións, ou ben a un interese persoal, un mecenas que aposte por esa lingua ou cultura e faga da súa exportación un labor individual que parte da admiración e paixón. Polo tanto, non resulta unha quimera, aínda que a vinculación cultural entre Galicia e Dinamarca sexa feble. No sentido oposto, as múltiples novelas de intriga ou negras importadas dos países nórdicos son best-sellers en moitos países, entre eles, España.

Este feito ten nome propio en Finlandia: o docente políglota da Universidade de Hensinki, Santerii Siimes; e sen esquecernos da súa predecesora, Taina Hämäläinen. Ámbolos dous fixeron da implementación do galego no país nórdico unha empresa persoal que deu os seus froitos. En palabras de Siimes, "a Universidade de Helsinki pode estar orgullosa de ser a única nos Países Nórdicos na que se ensinan as cinco principais linguas da Península Ibérica: castelán, portugués, catalán, galego e éuscaro" . O galego está incluído no Departamento de Linguas Modernas e, de novo, constatamos o factor de que exista xa a docencia de castelán e portugués para a introdución do galego.

Para que a universidade se interesase na colaboración coa Xunta, o papel de Taina Hämäläinen debeu de ser primordial, e seguro que tamén contou co apoio do catedrático de linguas iberorrománicas, Timo Riiho. Daquela xa se ensinaban aquí castelán e portugués, creo que catalán tamén, o que puido favorecer a introdución doutra lingua iberorrománica (...) Se foi posible aquí, non sei por que non o sería en Dinamarca. (Santeri Siimes)

Santeri Siimes, ademais de ser profesor de galego, e o responsable do Centro Estudos Galegos en Finlandia. $\mathrm{O}$ único que existe nos cinco países nórdicos, polo que non resultaría fóra de lugar erixir un novo, como xa explicamos no epígrafe anterior.

Resulta canto menos rechamante como un finlandés que comezou a estudar galego por ser unha lingua romance máis a engadir na súa longa lista de idiomas que domina, fale con tanto agarimo da nosa lingua e cultura. "Galicia engaioloume para sempre", chega a afirmar na conversa mantida sobre a súa primeira viaxe á nosa terra, que non deixa de visitar dende daquela. E déixanos unha pequena reflexión sobre a teima coa que abrimos este debate sobre debilidades e fortalezas do galego como lingua exportable.

A valorización e a normalización, pois, van xuntas: cando a lingua conte con todo o apoio institucional posible (...) e cando todos en Galicia aprendan a apreciar o que teñen de seu, a lingua como expresión máxima da cultura e parte importantísima da identidade (do pobo e mais do individuo), e se sintan orgullosos por ela, será posible -iso espero- chegar a unha normalización real. (Santeri Siimes, entrevista persoal)

\section{A AUSENCIA OU A OPORTUNIDADE}

\subsection{O PROXECTO}

Unha vez analizados os factores a ter en conta para entender o contexto dunha "non presenza" dunha lingua, neste caso o galego,

\footnotetext{
${ }^{9}$ Declaracións extraídas dunha entrevista persoal de elaboración propia.
} 
noutro país, temos que dar un paso máis e atrevernos a esgrimir un discurso optimista sobre a achega do galego a un país pequeno, como é Dinamarca, cunha cultura tan afastada da nosa como é a dos dinamarqueses. Do coñecemento poderíamos pasar, nun tempo prudencial, a un asentamento e un prestixio.

Os tres vértices xa explicados e utilizados na relación de argumentos son a educación, a tradución e o mercado editorial e o ámbito social. Este último, entendido como un punto de encontro emigrante, un centro social como os 185 que se espallan polo mundo (Suárez e Gaiferos 2011: 29): contar só cunha poboación galega inmigrante de 128 persoas ${ }^{10}$ constituiría unha posibilidade de expansión limitada. $\mathrm{O}$ certo é que a Xunta de Galicia recolle no seu Informe da Emigración o centro "Círculo Galaico", o punto de encontro emigrante en Copenhagen, pero a última referencia que ofrece data do 1988 e pouco máis de 100 afiliados; polo tanto, é un dato que non se pode tomar como referente actual.

Os puntos con máis forza serían a educación universitaria, onde o galego encontraría o seu oco entre o ensino do español e do portugués. Un Centro de Estudos Galegos e a materia impartida nas aulas universitarias serían as súas dúas bases. A presenza dunha lingua nunha universidade leva consigo o intercambio de coñecemento: conferencias, doutoramentos, colaboracións e outras actividades culturais.

No tocante á tradución e ó mercado editorial, alén do exposto na epígrafe anterior, o énfase debe poñerse no concepto de colaboración entre rexións a intercambiar os seus bens culturais e apoiarse na rede de subvencións e axudas institucionais. Ademais, non só se ha de entender o mercado editorial como a tradución de libros, senón todas as actividades anexas á edición. A profesora Luna Alonso fai fincapé nesta realidade multifactorial cando expón o seguinte:

Así e todo, a tradución non é só a que transmite e transforma o capital cultural ou a riqueza patrimonial dunha sociedade. Entre os factores que transmiten o capital atópanse tamén as institucións literarias, as revistas, os xurados, os críticos, os sistemas de ensino, etc. (2005: 34)

Tendo sempre en mente o referente finlandés, non debe verse como un impedimento entre as diferenzas culturais da rexión cultural de orixe e a de acollida. O proxecto pode ser apoiado con esforzos individuais e, deste xeito, comezar a elaborar unha rede de colaboración partindo da experiencia satisfactoria na Universidade de Helsinki. Igualmente, entenderíanse como apoios a presenza de traducións de obras galegas en Noruega e Finlandia (O lapis do carpinteiro de Manuel Rivas) e Domingo Villar en Suecia (Ollos de auga e A praia dos afogados), quen se achegou ó mercado sueco grazas a ser finalista do prestixioso galardón á mellor novela negra traducida do 2010 recoñecido pola Svenska Deckarakademic ${ }^{11}$.

Por suposto, non debemos esquecer, a pesar da motivación e o entusiasmo, o que María Luz Suárez e Alexandre Gaiferos nos fan lembrar, o cada vez máis globalizado mundo é un feito ineludible.

O futuro do galego como una lingua rexional ou minoritaria, ensinada nas universidades europeas e no mundo, é incerta. (...) Á vez que a economía mundial convértese nunha máis integrada, a lingua común convértese en máis importante ca nunca para promover o comercio, e

${ }^{10}$ Dato recollido do Informe da Emigración 2013, elaborado pola Xunta de Galicia (recurso dispoñible en: http://emigracion.xunta.es/conecendo-galicia/aprende/a-emigracion-en-cifras). Este dato pódese ver incrementado, xa que só conta coa xente inscrita oficialmente.

${ }^{11}$ A academia sueca da novela negra, un xénero moi específico que deu proxección internacional á literatura nórdica. As novelas negras ocupan os estantes dos libros máis vendidos e os escritores escandinavos están máis de moda que nunca: Jo Nesbø, Henning Mankel, Stieg Larsson ou Jussi Adler-Olsen; este último de orixe dinamarqués. 
isto non só pon a lingua rexional ou minoritaria nunha clara desvantaxe, senón que ameaza a súa existencia. (2011: 69)

\subsection{AXUDAS E SUBVENCIÓNS: XUN- TA DE GALICIA, UNIÓN EUROPEA E GOBERNO DINAMARQUÉS}

As axudas e subvencións son un elemento fundamental a ter en conta. Nesta epígrafe resumiremos as tres fontes máis relevantes no tema que nos ocupa: a Xunta de Galicia, a Unión Europea e o Goberno Dinamarqués. De todos modos, servirá só como unha referencia sucinta, non comparable á complexidade das distintas modalidades de apoios económicos que posúen os distintos órganos institucionais.

Que se elabore e publique a tradución dunha obra literaria galega no exterior non é un feito casual, senón que responde a algún motivo concreto que pode ir desde o interese académico ou literario ao rendemento comercial, pasando por unha política de subvencións eficaz etc. Doutra banda, convén non esquecer que se trata da relación entre dúas comunidades e se até o momento puxemos o foco de atención na comunidade galega en tanto que exportadora, non se deberan deixar de lado no futuro a análise da situación e o desenvolvemento da cultura meta desa tradución, que será determinante para coñecermos a función desa tradución. (Galanes Santos 2013: 283).

A Xunta de Galicia comezou cos seus programas de axudas á tradución no ano 1987. Como sinala a profesora Montero Küpper, "a partir de 1995 contamos con, polo menos, unha editorial estranxeira ou nacional por ano que recibe unha axuda para a tradución e edición dunha obra galega" (2013: 48). Xa en 2011, o importe presupostado en termos de axudas á tradución da Xunta, segundo datos fornecidos por esta estudosa, redúcese de 300 a 200 mil euros respecto ó ano 2010. Como datos máis recentes, subliñaremos que "ascende a cerca de 168 mil euros que se librarán entre os anos 2012 e 2013 (aprox. 75566 para 25 traducións de textos galegos e 92500 euros para traducións ao galego)" (2013: 51). Malia que os datos parecen ser esperanzadores, o $80 \%$ dos casos no 2012 corresponden a traducións do e para o castelán ou a outras linguas do territorio español ${ }^{12}$. Montero Küpper tamén cita a Skrabec (2013: 41), quen lembra que "as editoriais estranxeiras esperan que as traducións reciban apoio financeiro desde o país de orixe". Un concepto a ter en conta, se consideramos a posibilidade da exportación e de abrir mercados novos para a nosa literatura.

Doutra banda, a Unión Europea presenta diferentes programas para fomentar o intercambio cultural entre os países membros. Destacaremos o proxecto "Creative Europe, Culture Sub-Programme: Support to literary translations projects"13, do que se encarga a Comisión Europea. Os obxectivos e prioridades que presentan nas bases das súas axudas públicas son lóxicas e acordes á finalidade da unión: "apoiar a diversidade cultural e lingüística na Unión e outros países participantes". Ademais, salientan o propósito de "promover a circulación transnacional de obras literarias de gran calidade, do mesmo xeito que a mellora ó acceso a estes traballos na Unión Europea". Os proxectos que serían obxecto destas axudas económicas serían aquelas "traducións dende linguas minoritarias (incluíndo todas as linguas oficiais recoñecidas nos estados membros da Unión Europea, bardante do inglés, o alemán, o francés e o español (castelán)". En resumo, foméntase a tradución dende e para unha lingua minoritaria.

O Goberno Dinamarqués leva a cabo distintas accións co fin da protección da súa lingua e favorecer o intercambio cultural. O Statens Kuntsfond ${ }^{14}$, ou o que é o mesmo, o Fondo

\footnotetext{
${ }^{12}$ As restantes traducións son ás linguas alemá, búlgara, italiana e xaponesa (Montero Küpper 2013: 52).

${ }^{13}$ Fondos europeos para a tradución (recurso dispoñible en: https://eacea.ec.europa.eu/creative-europe/ actions/culture/literary-translation en).

${ }^{14}$ Máis información na páxina oficial, dispoñible en dinamarqués e inglés (http://www.kunst.dk/kunsts $\underline{\text { toette/). }}$
} 
Estatal da Arte, pon en marcha de maneira periódica distintas bolsas á tradución de obras, do mesmo xeito que fomentan outros aspectos artísticos, facendo fincapé na divulgación do dinamarqués e outras linguas nórdicas.

\section{CONCLUSIÓNS}

Para rematar este percorrido pola presenza ou, mellor dito, ausencia do galego en Dinamarca, lembramos os puntos chave deste estudo. Un traballo que non é máis que unha sucinta achega ó que, desexamos, sexa o punto de partida dunha investigación con futuro. A poboación emigrante galega é reducida en Dinamarca, o que non impediría unha implementación do coñecemento do galego. Ademais, estamos nun momento histórico de expansión do colectivo emigrante, debido ás circunstancias socioeconómicas.
O galego e o dinamarqués son linguas minoritarias, ocupando os postos 23 e 29, respectivamente, no uso en Europa. Partindo da lóxica diferenza de unha delas ser a lingua oficial do Estado, coa súa correspondente blindaxe e apoio, os dous pobos teñen culturas de forte calado na sociedade.

O estudo confirma a inexistencia de mostras de literatura galega en traducións ou en círculos académico-sociais. Porén, Dinamarca constitúe un mercado emerxente e con posibilidades de expansión, debido ó inicio da introdución do galego en Noruega, Suecia e Finlandia. A proposta de implementación susténtase en tres ámbitos fundamentais: a universidade, o mercado editorial e o ámbito social. Agora só queda comezar a traballar para facelo realidade.

\section{REFERENCIAS BIBLIOGRÁFICAS ${ }^{15}$}

CASARES Mouriño, Carlos (dir.) (2003): Catálogo de obras literarias en lingua galega traducidas a outros idiomas. Unha primeira achega. Santiago de Compostela: Consello da Cultura Galega (dispoñible en: http://consellodacultura.gal/mediateca/extras/catalogo traducidas.pdf).

Castro, Salvador, Henrique Harguindey, Xosé Martínez e Ramón Rocamonde (2011): Urbi et Orbi: Dende o galego para o mundo. Pontevedra: Idea Gráfica Profesional.

GALANES SANTOS, Iolanda (2013): “A tradución exterior da obra galega. Normalización dunha cultura emerxente?", en M. Mosquera (ed.), Lingua e Tradución. IX Xornadas sobre Lingua e Usos. A Coruña: Universidade, pp. 265-287.

GonzÁlez González, Manuel (2006): “O ensino do galego como lingua estranxeira”, en Instituto Cervantes, Enciclopedia del español en el mundo: Anuario del Instituto Cervantes 20062007. Madrid: Plaza de Janés Editores, pp. 389-397.

Luna Alonso, Ana (2005): “A literatura galega traducida no extranxeiro: un intercambio desigual”, Grial. Revista galega de cultura 167, pp. 32-45.

MÉNDeZ Ferrín, Xosé Luís (2013): “A internalización da cultura galega”, en M. Mosquera (ed.), Lingua e Tradución. IX Xornadas sobre Lingua e Usos. A Coruña: Universidade, pp. 35-39.

Montero KüPPER, Silvia (2013): “As políticas de tradución no caso galego", en M. Mosquera (ed.), Lingua e Tradución. IX Xornadas sobre Lingua e Usos. A Coruña: Universidade, pp. 41-59.

\footnotetext{
${ }^{15}$ Entrevistas persoais feitas a Salvador Castro, Henrique Harguindey, Alejandro Tobar, Morten Dürr, Nieves Hérnandez-Flórez e Santeri Siimes: O máis agarimoso agradecemento a todos eles polo seu tempo e por compartir comigo a súa sabedoría.
} 
Recuenco Peñalver, María (2011): "Más allá de la traducción: la autotraducción”, Revista Trans 15, pp. 193-208.

SuÁrez, María Luz e Alexandre GAIFERos (2011): The integration of Regional or Minority Languages in the European Higher Education Area: Galician as a Case Study. Bilbao: Universidade de Deusto. 